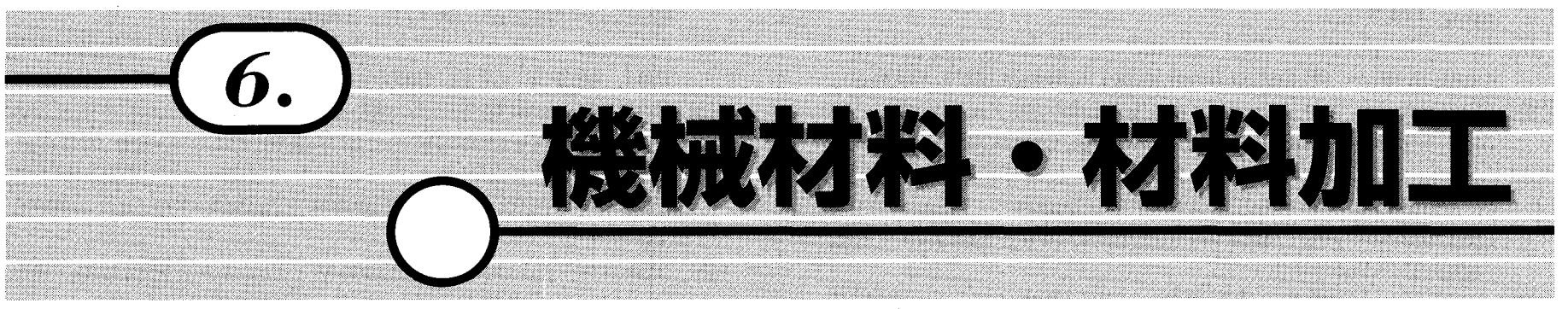

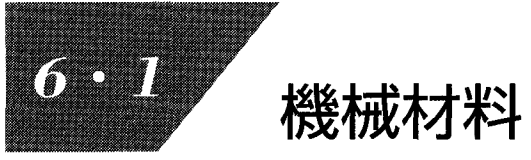

\subsection{7 鉄鋼材料}

a. 生産 2008 年 9 月のアメリカ金融機関の破綻を契機と した世界経済の急激な減速の影響の余波により，2008 年度第 4 四半期の国内粗鋼生産は 1760 万 $\mathrm{t}$ となり，1970 年以来の歴 史的低水準となった．鉄鋼各社の大減産による在庫調整の進展 に加え, 自動車・電機の生産量回復やアジア地域への輸出増加 により，2009 年度第 3 四半期には国内粗鋼生産量は 2660 万 $\mathrm{t}$ まで回復したが，2009 暦年では 2008 年対比 $26 \%$ 減の 8753 万 $\mathrm{t}$ に留まった。一方，今世紀に入ってからの中国での目覚ま しい生産量の拡大は依然続いており，2009 年は世界初の 5 億 6 千万 $\mathrm{t}$ を超える粗銅生産量を記録した.

b. 研究・新設備動向 新日本製鐵（株）大分製鉄所の第 1 高炉の改修工事が完了し，再稼働した。また，住友金属工業 （株）の和歌山製鉄所では第 4 高炉からの切り替えで新第 1 高 炉が稼働した。いずれも，炉体維持技術と解析技術の導入によ り，20 年乃至 25 年以上の炉寿命が計画されている. 研究開発 では, 環境・エネルギー問題に貢献しうる鉄鋼プロセスならび に材料に関する取り組みが活発に行われている。（社）日本鉄 鋼連盟，鉄鋼各社によるプロジェクト「環境調和型製鉄プロセ 不技術開発（COURSE50)」は 2 年目を迎えている，炭素を用 いない鉄鉱石還元技術と新たな $\mathrm{CO}_{2}$ の分離回収による革新的 技術開発を軸に 2050 年へ向けて鉄鋼業界の排出量を $30 \%$ 削減 することを目標にしている，一方，足下の行動計画として， $2008 \sim 2012$ 年の鉄鋼生産工程におけるエネルギー消費量を 粗鋼生産量 1 億 $\mathrm{t}$ を前提として基準年の 1990 年度に対し $10 \%$ 削減する目標を揭げ，2008 年度では粗鋼量当たり $8.6 \%$ 改善し たとの報告がなされた，自動車用鋼板に関して，ハイブリッド 車のような環境対応車の需要が世界的に急激に高まった。 世界 鉄鋼メ一カで構成される World Auto Steel は，次世代鋼製車 体プログラム（Future Steel Vehicle：FSV) を2008 年から 立ち上げているが，2009年 9 月にその中間報告がなされ，今 後の活動計画が発表された. 車体設計技術と鉄鋼技術を駆使し 対 2001 年〜 2008 年モデル車のホワイトボデー重量比 35\%減 等の目標を揭げている.NEDO プロジェクト「鉄鋼材料の革 新的高強度・高機能化」は 3 年目を迎えている. 鋼構造物，工 ネルギープラントの高強度・高機能化・長寿命化, 自動車等の 軽量化を可能とするための溶接技術や制御鉔造技術等の開発を 目指している。

〔黒田 浩一 住友金属工業(株)〕

\subsection{2 非鉄金属材料}

a. アルミニウム 2009 年のアルミ製品の総出荷量は 325 万 $\mathrm{t}$ （前年比 $76.6 \%$ ）となった

アルミニウム圧延品の出荷量は 174 万 $\mathrm{t}(78.3 \%)$ であり 3
年連続のマイナスとなった。出荷量が 200 万 $\mathrm{t}$ を割り込むのは 1987 年以来であり, 実に 22 年ぶりの記録的な減販年となった.

圧延品出荷量の内訳は，板類が 107.4 万 $\mathrm{t}(79.9 \%)$. 減少の 要因は自動車 ·䇴地などの主要分野が軒並み大幅減となったこ とによる. また，押出し類は 66.9 万 $\mathrm{t}(76.0 \%)$. 主力の建設 関連の需要減少に柬止めがかからず, また自動車関連需要も大 きく減少したのが主な要因である。

需要が大幅に減少した最大の要因は, リーマン・ブラザーズ 破綻による世界経済危機の継続的影響による. アルミ業界各社 は需要減少による減産対応として, 操業停止や工場統廃合など 生産体制の再構築を余儀なくされる 1 年となった.

技術動向は，車両用アルミニウム材の接合技術としてすでに 普及している摩擦擋捧接合 (FSW) 技術をもとに, それをスポッ ト接合に応用した「摩擦靦拌スポット接合FSSW (Friction Stir Spot Welding)」技術や「摩擦擤抖プロセス FSP (Friction Stir Processing)」技術などが新たに紹介されている.

材料開発では, 深海探查機に搭載される電子機器等を収納す る深海耐圧容器用新素材として, CFRP（炭素繊維強化プラス チック）とアルミニウム合金とを積層したハイブリッド材が研 究されている. また, アルミニウム協会では今後 25 年間の研 究・技術開発の方向性を示す「アルミニウム技術戦略ロード マップ」を策定し研究を進めて打り，未来のアルミ産業に向け て業界共通の基盤技術開発への取り組みが行われている.

b. マグネシウム マグネシウムの 2009 年度の国内需要は, 2.9 万 $\mathrm{t}$ 程度であり, 2008 年度に比べて $30.2 \%$ 減と大幅減少となった.

用途別内訳ではダイカスト, 鋳物, 射出成形などの構造材用 途が 0.65 万（前年比 $70.7 \%$ ）. 添加材用途としては，アルミ 合金添加用途材が 1.4 万 $\mathrm{t}$ で $30.4 \%$ の減, 鉄鋼脱硫用途材が 0.55 万 $\mathrm{t}$ で $30.0 \%$ 減となった.

c. 銅銅および銅合金の 2009 年の出荷量は 66 万 $\mathrm{t}$ となっ た.（前年比 $69.6 \%)$ 出荷の内訳は銅製品 34.4 万 $\mathrm{t}(71 \%)$ で板. 条が 19.9 万 $\mathrm{t}$, 管・棒が 14.2 万 $\mathrm{t}$, 黄銅製品は 26.9 万 $\mathrm{t}(67 \%)$ で板・条が 7.9 万 $\mathrm{t}$ ，管・棒が 16.3 万 t であった.

d. チタン 世界の航空機産業の低迷の影響から，2009 年 のチタン需要は 1 年を通じて非常に厳しいものとなった. 展伸 材需要は前年に比べ大幅に減少し, 展伸材出荷量は 1.2 万 $\mathrm{t}$ (前 年比 $63 \%$ ）となった. とくに国内向けは, 前年比 $59 \%$ 減の 0.4 万 $\mathrm{t}$ と電力分野を除くすべての用途別分野で前年を下回った. 輸出は, 国内向けと比較すると落ち込み幅は小さいものの前年 比 $18 \%$ 減の 0.78 万 $\mathrm{t}$ であった。

[安達章 日軽金アクト(株)]

\section{6-1.83 無機材料}

a. 生産 ${ }^{(1)} 2005$ 年に初めて 2 兆円を超えたファインセラミッ クスの部材生産額は, 2006 年, 2007 年と順調に推移した。（社） 日本ファインセラミックス協会（JFCA）が行っている産業動 向調査によれば, 2008 年には 2 兆 4340 億円に達する見込み であり, 前年度比 $1.6 \%$ とプラス成長が見込まれている. 主要 製品である電磁気・工学用が前年比 $2.2 \%$ 増 (1 兆 5834 億円), 